\title{
THE INTERACTION BETWEEN SULFATHIAZOLE AND COBALT(II): POTENTIOMETRIC STUDIES
}

\author{
Sebastián Bellú y Marcela Rizzotto* \\ Area Inorgánica, Universidad Nacional de Rosario, Suipacha 531, 2000 Rosario, Argentina \\ Nora Okulik \\ Facultad de Agroindustrias, Universidad Nacional del Nordeste, Cte. Fernández 755 (3700) Presidencia Roque Sáenz Peña, \\ Chaco, Argentina \\ Alicia Jubert \\ Departamento de Química, Facultad de Ciencias Exactas 47 y 115 y Facultad de Ingeniería 1 y 47, Universidad Nacional de La \\ Plata, (1900) Buenos Aires, Argentina
}

Recebido em 19/6/06; aceito em 17/11/06; publicado na web em 2/7/07

\begin{abstract}
Potentiometric studies of sulfathiazole (HST) in the presence and absence of cobalt(II) were performed. Equilibrium constants for the formation of the detected species, $[\mathrm{Co}(\mathrm{ST})]^{+}$and $[\mathrm{Co}(\mathrm{ST})(\mathrm{OH})]$, are reported. UV-Vis spectrophotometric measurements suggest that the coordination $\mathrm{Co}(\mathrm{II})$-sulfathiazole might be through a $\mathrm{N}$ atom, which, in agreement with $\mathrm{MO}$ calculations, could be a thiazolic one. In spite of sulfonamides being better ligands at $\mathrm{pH}>7,[\mathrm{Co}(\mathrm{ST})]^{+}$was found at $\mathrm{pH} \approx 3$.
\end{abstract}

Keywords: potentiometric studies; cobalt complexes; sulfathiazole.

\section{INTRODUCTION}

In the last few years, great interest has been paid to complexation studies of transition metal ions such as $\mathrm{Ag}(\mathrm{I}), \mathrm{Cd}(\mathrm{II})$ and $\mathrm{Co}(\mathrm{II})$ with nitrogen donor ligands in aqueous and non-aqueous solvents and both natural (metallo-proteins and -enzimes) and synthetic complexes of a number of transition metals. The main aims, which have a great academic and practical interest in general, were to improve knowledge of the coordination chemistry of soft and hard metal ions in solvents of different donating properties, to study how basicity and steric effects may affect the selectivity pattern in metal coordination ${ }^{1-5}$ and the binding, transport and activation of small molecules such as dioxygen, carbon monoxide, carbon dioxide, nitric oxide and sulfur dioxide. This purpose is very important in chemical, biochemical, biological, environmental and industrial fields $\mathrm{s}^{6-8}$. For example, Co(II) and other metal complexes play an important role in the industrial cleaning of gaseous effluents from power plants through the suggested simultaneous absorption of nitric oxide and sulfur dioxide ${ }^{9-11}$. Furthermore, the binding, transport and activation of molecular oxygen by metal complexes is a topic of wide current interest due to the many implications that such metal containing systems have in both biomimetic and abiotic processes involving dioxygen ${ }^{12}$.

In biology, $\mathrm{Co}$ (II) complexes are very important because they represent one of the most successful classes of synthetic oxygen carriers $^{13-15}$. In this sense, the $\mathrm{Co}(\mathrm{II})$ complexes with $\mathrm{N}$ donor ligands are known for their ability to bind dioxygen more or less reversibly and therefore frequently studied for their importance in industrial processes and as model compounds ${ }^{16-18}$.

Because of its high sensitivity to the coordination site geometry and the many experimental techniques that can be used in its characterization, cobalt has been used to replace other metal ions to gather information about changes in metal sites in proteins during protein function. Spectroscopic characterization of these systems has revealed that cobalt can be present as $\mathrm{Co}$ (II) and $\mathrm{Co}$ (III) ions in

*e-mail: mrizzot@agatha.unr.edu.ar several types of coordination, which lead to different electronic and magnetic properties. In this context, the use of simple Cocontaining systems with low molecular weight ligands is useful for understanding the correlation between spectroscopic and structural properties $^{19-22}$.

In medicine, the successful use of metal complexes as therapeutic and diagnostic agents depends on the control of their kinetic and thermodynamic properties through appropriate choice of oxidation state, types and numbers of bound ligands, and coordination geometry. In this way it is possible to achieve specificity of biological activity and, most importantly, to minimize toxic side-effects ${ }^{23}$. On the other hand, the chemical speciation of an element, either essential or toxic, allows the knowledge of its biodisponibility, transport and absortion properties in biofluids or tissues ${ }^{24}$. Mechanism of action and biotransformation studies are important because the active species may be a metabolite of the administrate metal complex ${ }^{23}$.

The binding of drugs to plasmic proteins, principally albumin and $\alpha$-glicoproteins, is one of the factors that affects the availability of drugs in the human body. Sulfonamides, $\mathrm{N}$ donor ligands, bind in different grades to plasmic proteins, which is related to the $p K_{a}$ of each sulfa-drug ${ }^{25}$. Neutral sulfonamides are expected to be poor ligands because of the withdrawal of the electron density from the nitrogen atom onto the electronegative oxygen atoms. However, if the sulfonamide $\mathrm{N}$ atom bears a dissociable hydrogen atom, this same electron-withdrawing effect increases its acidity and, in the deprotonated form, sulfonamide anions are effective s-donor ligands ${ }^{26}$. Sulfonamides were the first effective chemotherapeutic agents employed systematically for the prevention and cure of bacterial infections in humans $\mathrm{s}^{27,28}$. They are considered useful especially in the case of ophthalmic infections as well as infections in the urinary and gastrointestinal tract ${ }^{29}$. Besides, sulfadrugs are still today among the drugs of first election (together with ampicillin and gentamycin) as chemotherapeutic agents in bacterial infections by $E$. coli in humans ${ }^{25}$. The sulfanilamides exert their antibacterial action by the competitive inhibition of the enzyme dihydropterase synthetase towards the substrate $p$-aminobenzoate ${ }^{30}$. Sulfathiazole 
(4-amino- $N$-2-thiazolylbencenosulfonamide), HST (Figure 1), is clinically one of the most used ${ }^{31}$.

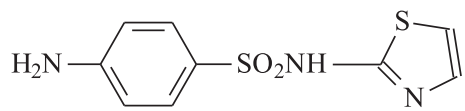

Figure 1. Sulfathiazole (HST)

Furthermore, sulfadrugs and their metal complexes, possess many applications, in addition to antibacterial activity, as diuretic, antiglaucoma or antiepileptic drugs, among others ${ }^{32-38}$, like antifungal activity ${ }^{39,40}$, and, in many cases, the activity of the metal complex is much better than the ligand one ${ }^{41}$.

Despite its low availability in the earth's crust ${ }^{42}$, cobalt plays important roles in biological systems. Cobalt is one of those trace elements, which is present in the human body as a metal cofactor, in the form of biologically important molecules, like the $\mathrm{B}_{12}$ coenzime and vitamin $\mathrm{B}_{12}{ }^{43}$. Cobalt is also well-known for its potent influence on human physiopathological conditions resulting either from its absence in the body, thereby leading to anemic symptomatology $\mathrm{y}^{44}$ or its presence in excess, emerging from professional or habitual exposure, leading to toxic effects, manifested in heart disease and excessive red corpuscle formation $^{45,46}$. The forms, however, with which low molecular mass physiological, like citrate ${ }^{47}$, or pharmacology ligands - like sulfathiazole - complex cobalt ions, thus affording soluble and potentially available species to biochemical process, are not wellknown. Moreover, knowledge of cobalt speciation patterns with medicament drugs that can act as ligands at physiological $\mathrm{pH}$ might be of fundamental importance in understanding the chemistry of the involucred biological processes ${ }^{47}$.

As part of a research program dedicated to the investigation of the structural, physicochemical and biological properties of metal complexes of sulfadrugs, in this paper we report the results of potentiometric studies of sulfathiazole in the presence and absence of cobalt(II) ion, in aqueous solution.

\section{EXPERIMENTAL}

\section{Materials and methods}

Sulfathiazole, as sodium salt (Sigma, >99\%), cobalt(II) chloride hexahydrate (Merck, GR), and all other chemicals, of commercially available reagent grade, were used as received. The stock solution of cobalt(II) chloride hexahydrated $\left(\mathrm{CoCl}_{2} \cdot 6 \mathrm{H}_{2} \mathrm{O}\right)$ was standardized by titration with EDTA (ethylenediaminetetraacetic acid) ${ }^{48}$. Potassium chloride, the supporting electrolyte, was obtained as reagent grade quality. Carbon dioxide-free $\mathrm{NaOH}$ was prepared by taking a 5.50 $\mathrm{mL}$ sample of clear $50 \% \mathrm{NaOH}$ solution (from the clear supernatant in the present of excess pure $\mathrm{NaOH}$ pellets -Sörensen solution- and diluting to $1.0 \mathrm{~L}$, followed by standardization with primary-standard potassium acid phthalate ${ }^{49}$. A Gran's plot indicated the absence $(<0.5 \%)$ of $\mathrm{CO}_{2}$ in the base $\mathrm{b}^{50}$. Manipulations were carried out in the open air $^{47}$. Since Co(II), however, is sensitive to oxidation to the inert $\mathrm{Co}$ (III) form in basic media, potentiometric titrations were carried out under a nitrogen atmosphere, both to prevent oxidation of $\mathrm{Co}$ (II) and besides in order to exclude carbon dioxide from the system.

\section{Potentiometric equilibrium measurements}

Potentiometric studies of sulfathiazole, as sodium salt (NaST), in the absence and presence of $\mathrm{Co}$ (II) were carried out with a Corning $350 \mathrm{pH}$ meter equipped with glass combination electrodes calibrated with $\mathrm{HCl}$ to read $-\log \left[\mathrm{H}^{+}\right]=\mathrm{p}[\mathrm{H}]$. The electrode was calibrated using both the data from potentiometric titration of a known volume of a standard $0.0100 \mathrm{HCl}$ with a standard $0.100 \mathrm{M} \mathrm{NaOH}$ and from the standardization by titration with primary-standard sodium carbonate ${ }^{49}$. The ionic strength of the $\mathrm{HCl}$ solution was maintained at $0.100 \mathrm{M}$ by addition of $\mathrm{KCl}$. The temperature was maintained at $25.0^{\circ} \mathrm{C}$ and the experimental solutions, adjusted to $0.100 \mathrm{M}$ ionic strength by addition of $\mathrm{KCl}$, were titrated with $0.100 \mathrm{M}$ standard $\mathrm{CO}_{2}$-free $\mathrm{NaOH}$. Potentiometric studies were carried out on 50.00 $\mathrm{mL}$ of experimental solution in a thermostated cell, purged with nitrogen cleaned by an $0.1 \mathrm{M} \mathrm{NaOH}$ solution. Each potentiometric titration was done at least three times. 30 to 40 points were acquired per $\mathrm{p}[\mathrm{H}]$ profile providing in general at least 10 pairs of data (volume base, $\mathrm{p}[\mathrm{H}]$ ) per neutralisation equivalent. Equilibrium measurements were made on solutions containing 2:1 molar ratio of NaST to metal ion. Molar ratios greater than 2:1 (e.g., 4:1) were tried unsuccessfully because of the precipitation of sulfathiazole in these conditions. The initial $\mathrm{p}[\mathrm{H}](\mathrm{ca}$. 2.) was obtained by the addition of enough quantity of $\mathrm{HCl} 0.0100 \mathrm{M}$ : two equivalents per mole of solid NaST. $\log K_{w}$ for the system, defined in terms of $\log$ $\left(\left[\mathrm{H}^{+}\right]\left[\mathrm{OH}^{-}\right]\right)$, was maintained fixed at -13.78 during the refinements ${ }^{50}$. All stability constants and the standard deviations in the refined constant were determined using procedures outlined in detail in the literature $\mathrm{e}^{50}$. The errors were estimated as about four times the $\mathrm{s}_{\mathrm{fit}}$ (which is the standard deviation computed from calculated $\mathrm{pH}$ values compared to experimental values) because of additional uncertainties in weight of sample, volume of titrant, etc. ${ }^{51}$.

\section{Potentiometric computations}

Computations were carried out with the BEST program ${ }^{50}$, and random error analysis in the determination of equilibrium constants with the ERRBEST program ${ }^{52}$. Species diagrams were obtained with SPE and SPEPLOT programs ${ }^{50}$.

\section{Spectrophotometric studies}

Measurements of UV-Vis spectra were carried out between 200 and $800 \mathrm{~nm}$ in a Jasco model 530 double beam spectrophotometer, using quartz cells of $1 \mathrm{~cm}$ path length.. The spectrophotometer was equipped with a thermostated cell compartment to maintain the temperature at $25.0^{\circ} \mathrm{C}$. Samples of about $0.040 \mathrm{mmol}$ of NaST and $0.020 \mathrm{mmol}$ of $\mathrm{Co}$ (II) were diluted to $20.00 \mathrm{~mL}$ in a sealed thermostated vessel at $25.0^{\circ} \mathrm{C}$, equipped with the combined glass electrode calibrated as described above for the potentiometric measurements ${ }^{53}$. The ionic strength was maintained at $0.100 \mathrm{M}$ by the addition of $\mathrm{KCl}$. The $\mathrm{p}[\mathrm{H}]$ values of solutions were adjusted by addition of small volumes of $0.100 \mathrm{M} \mathrm{NaOH}$ or $\mathrm{HCl}$ with a microburet attached to the thermostated vessel. About $3 \mathrm{~mL}$ of these solutions were transferred to the quartz cell into the spectrophotometer, with the reference containing $0.100 \mathrm{M} \mathrm{KCl}$. All conditions were adjusted to the potentiometric ones, in order to avoid: precipitation of sulfathiazole at low $\mathrm{p}[\mathrm{H}]^{54}$, precipitation of cobaltous hydroxide above $\mathrm{p}[\mathrm{H}] \approx 8^{55}$ and presence of polymeric species of $\mathrm{Co}(\mathrm{II})$ near neutral $\mathrm{pH}$ before precipitation starts ${ }^{56}$ and trying that the spectra represent the same species detected by the potentiometric measurements.

\section{Molecular orbitals studies}

\section{Atoms-in-molecules theory}

The Atoms-in-Molecules (AIM) theory permits to follow the Lewis standpoint of a chemical reaction, to determine the 
electrophilic and nucleophilic zones of a molecule from the topology and topography of the Laplacian of the charge density, $\nabla^{2} \rho^{57}$. It is based upon the critical points (CPs) of the molecular charge density, $\rho(r)$. At these points, the gradient of the electronic density, $\nabla \rho(r)$, is null and it is characterized by means of the three eigenvalues, $\lambda_{\text {i }}$ ( $\mathrm{i}=1,2,3)$, of the $\rho(\mathrm{r})$ Hessian matrix CPs are named and classified as $(r, s)$ according to their rank, $r$ (number of nonzero eigenvalues), and signature, $s$ (the three eigenvalues algebraic sum). In molecules there are four types of CPs having special interest: $(3,-3),(3,-1)$, $(3,+1)$ and $(3,+3)$.

A $(3,-3)$ critical point corresponds to a maximum in $\rho(r)$, characterized by $\nabla^{2} \rho(\mathrm{r})<0$ and occurs usually at the nuclear positions. A $(3,+3)$ critical point relates to a decreasing of the electronic charge and it is characterized by $\nabla^{2} \rho(r)>0$. This point is also known as cage critical point. $(3,+1)$ points or ring CPs, are saddle points. Finally, a $(3,-1)$ point or bond $\mathrm{CP}$, is located frequently between two neighboring nuclei, denoting the existence of a chemical bond between them.

Several properties evaluated at the bond critical point $(\mathrm{BCP})$ make up powerful tools to classify a given chemical structure ${ }^{58}$. Briefly, two negative eigenvalues of the Hessian matrix $\left(\lambda_{1}\right.$ and $\lambda_{2}$, respectively) measure the degree of contraction of $\rho(\mathrm{r})$ at a normal direction to the bond towards the $\mathrm{BCP}$, while a positive eigenvalue (i.e., $\lambda_{3}$ ) gives a quantitative indication of the contraction degree parallel to the bond and from the BCP towards each of the neighboring nuclei. Calculated properties at the BCP of the electronic density are labeled with the subscript "b" throughout the work.

In the AIM theory atomic interactions are classified according to two limiting behaviors, namely, shared interactions and closedshell interactions. Shared interactions are characteristic of covalent and polarized bonds and their main features are large values of $\rho_{\mathrm{b}}$, $\nabla^{2} \rho_{\mathrm{b}}<0,\left|\lambda_{1}\right| / \lambda_{3}>1$ and $E_{\mathrm{b}}<0, E_{\mathrm{b}}$ being the local electronic energy density of the system calculated at the BCP and defined as the sum of the local kinetic energy density and the local potential energy density, both computed at the $\mathrm{BCP}^{57}$. In contrast, closedshell interactions, useful to describe ionic bonds, hydrogen bonds, and van der Waals interactions, are characterized by small values of $\rho_{\mathrm{b}}, \nabla^{2} \rho_{\mathrm{b}}>0,\left|\lambda_{1}\right| / \lambda_{3}<1$ and $E_{\mathrm{b}}>0$.

AIM theory permits the identification of reactive sites by means of the Laplacian of the charge density, $\nabla^{2} \rho$. AIM defines the valenceshell charge concentration (VSCC) as the outer molecular zone where $\nabla^{2} \rho<0$. This zone is the one which, upon chemical combination, is distorted to yield non-bonded critical points $\left(\mathrm{NBCP}\right.$ ), which are minima in $\nabla^{2} \rho$ (maxima of charge concentration), corresponding in number and position to the electron pairs defined by the Lewis and related models ${ }^{57,59}$. NBCP correspond to zones where an electrophilic attack can occur.

\section{Calculation details}

The conformational space for the sulfathiazole, HST, and the anion sulfathiazolate, $\mathrm{ST}^{-}$, was studied using the molecular dynamics (MD) module of the HyperChem package ${ }^{60}$. Several simulations were accomplished with the aid of the $\mathrm{MM}+$ force field also available in that package. The starting geometries were heated from 0 to $600 \mathrm{~K}$ in $0.1 \mathrm{ps}$. Then, the temperature was kept constant by coupling the system to a simulated thermal bath with a bath relaxation time of $0.5 \mathrm{ps}$. The simulation time step was $0.5 \mathrm{fs}$. After an equilibration period of 1 ps a 500 ps-long simulation was run saving the coordinates every 1 ps. Those geometries were then optimized to an energy gradient less than $0.001 \mathrm{kcal} \mathrm{mol}^{-1} \AA^{-1}$ using the MM+ force field.

The lowest energy conformers of the molecules were further studied using the density functional theory as implemented in the
Gaussian 98 package $^{61}$. Geometry optimizations were performed using the Becke's three parameter hybrid functional ${ }^{62}$ with the LeeYang-Parr correlation functional ${ }^{63}$, a combination that gives rise to the well known B3LYP method. The $6-31+\mathrm{G}^{* *}$ basis set is used for all the atoms. The fully optimized molecular geometries were characterized as minima in the potential energy surface by the absence of imaginary vibrational frequencies. Calculations were carried out with Gaussian 98 package ${ }^{61}$ using the density functional theory (DFT) and the same basis set as above.

Topological analysis and the local properties evaluation were made with the PROAIM software ${ }^{64}$ using the wave functions calculated at the B3LYP level and the $6-311++\mathrm{G}^{* *}$ basis set implemented in the Gaussian 98 computer program ${ }^{61}$. The graphs of structures and the contour maps of the charge density Laplacian were obtained with the help of the PROAIM program ${ }^{64}$.

\section{RESULTS AND DISCUSSION}

\section{Species formed in the Co(II)-sulfathiazole system}

In the development of new fields like bioinorganic chemistry, stability constants are a powerful tool, with the aims of appropriate computer programs, for the elucidation of the molecular and ionic species present in biological and environmental systems ${ }^{50}$.

The protonation constants of sulfathiazole were calculated from titration data under the present experimental conditions. The potentiometric titration curve for a mixture of sulfathiazole with $\mathrm{Co}(\mathrm{II})$ in a molar ratio: $[\mathrm{NaST}] /[\mathrm{Co}(\mathrm{II})]=2 / 1$ is shown in Figure 2, together with the titration curve of the ligand. In the titration curve of the sulfathiazole, HST, the reaction of two $a$ values ( $a=$ mole of $\mathrm{NaOH} /$ mole of ligand) of base indicate two protonation steps, which occur in two buffer regions: one at $\mathrm{p}[\mathrm{H}]$ near 7.5 and another at $\mathrm{p}[\mathrm{H}]$ near 2.5, due to the presence of the amido group (log $K=7.24)$ and the amino group $(\log K=2.32)$, respectively. These two curves \%ligand alone and ligand plus $\mathrm{Co}(\mathrm{II}) \%$ do not show coincidence in any region, suggesting that there is complexation between both ligand and the metal ion in the range of $\mathrm{p}[\mathrm{H}]$ considered $^{50}$.

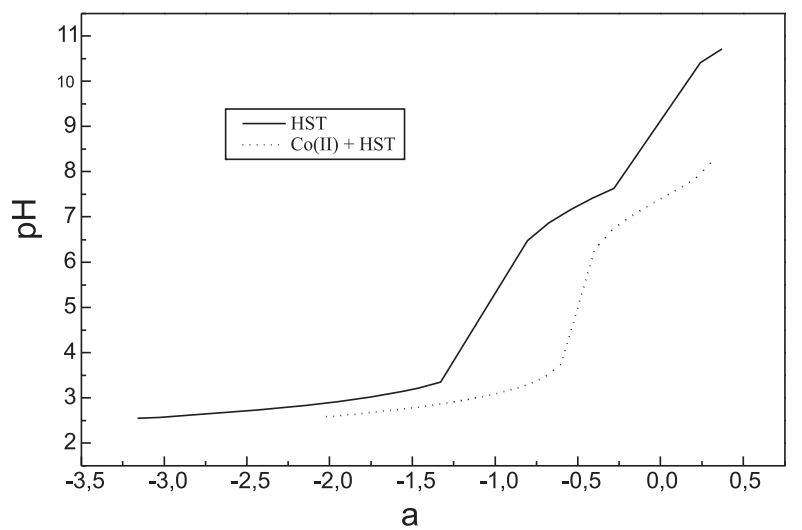

Figure 2. Potentiometric equilibrium curves for the Co(II)-sulfathiazole system, at $25.0^{\circ} \mathrm{C}$ and $\mathrm{I}=0.100 \mathrm{M}(\mathrm{KCl})$. Initial conditions: HST: 0.08048 mmol of sulfathiazole (as sodium salt, NaST) and $0.25438 \mathrm{mmol} \mathrm{HCl} \mathrm{in} 50.00$ mL of solution; Co(II) + HST: $0.1038 \mathrm{mmol} \mathrm{NaST,} 0.20978 \mathrm{mmol} \mathrm{HCl}$ and $0.04810 \mathrm{mmol}$ of $\mathrm{Co}(\mathrm{II})$ in $50.00 \mathrm{~mL}$ of solution. ( $a=$ moles of $\mathrm{NaOH}$ added per mole of ligand)

The equilibrium constants found for the formation of complexes between sulfathiazole and $\mathrm{Co}$ (II) are defined by the following Equations, where $\mathrm{L}^{-}$represents the deprotonated ligand: sulfathiazolate, and $\mathrm{M}$ represents $\mathrm{Co}(\mathrm{II})$ : 
$\mathrm{L}^{-}+\mathrm{M}^{2+}=\mathrm{ML}^{+} \quad K=\left[\mathrm{ML}^{+}\right] /\left[\mathrm{L}^{-}\right]\left[\mathrm{M}^{2+}\right]$

$\mathrm{L}^{-}+\mathrm{M}^{2+}+\mathrm{OH}^{-}=\mathrm{M}(\mathrm{OH}) \mathrm{L} \quad K=[\mathrm{M}(\mathrm{OH}) \mathrm{L}] /\left[\mathrm{L}^{-}\right]\left[\mathrm{M}^{2+}\right]\left[\mathrm{OH}^{-}\right]$

In the presence of $\mathrm{Co}(\mathrm{II})$, the buffer region at lower $\mathrm{p}[\mathrm{H}]$ (near $\mathrm{p}[\mathrm{H}] 3$ ) is extended with respect to the ligand alone, and another $a$ value is consumed, which is indicative of the formation of a specie $\mathrm{ML}^{+}$. Another extra $a$ value is consumed in the alkaline region, which is indicative of the formation of another coordinated specie between sulfathiazole and $\mathrm{Co}(\mathrm{II})$ : the neutral one $\mathrm{ML}(\mathrm{OH})$

The large increase of $\mathrm{p}[\mathrm{H}]$ in curve $\mathrm{Co}(\mathrm{II})+\mathrm{HST}$, which occurs at $c a$. $0.5 a$ value plus than the corresponding increase in curve corresponding to HST alone, suggests completion of 1:1 complex formation $^{50}$. The titration of the Co(II)-sulfathiazole system could be extended only to $\mathrm{pH} c a$. 8.2 because of the precipitation of a pink solid at upper $\mathrm{pH}$, that could be attributed to the complex $\left[\mathrm{Co}^{\mathrm{II}}(\mathrm{ST})_{2}\left(\mathrm{H}_{2} \mathrm{O}\right)_{4}\right](\mathrm{s})^{65}$.

The curves were analyzed and the best fit between the experimental and calculated titration curves was obtained by considering the species $[\mathrm{CoL}]^{+}$and $[\mathrm{CoL}(\mathrm{OH})]^{0}$, where $\mathrm{L}$ represents the deprotonated sulfathiazole $\left(\mathrm{L}=\left[\mathrm{C}_{9} \mathrm{H}_{8} \mathrm{~N}_{3} \mathrm{~S}_{2} \mathrm{O}_{2}\right]^{-}\right)$. Other complexes, like CoHL, or other protonated or deprotonated species were rejected by the computer program during the calculation process.

The values of the equilibrium constants obtained are reported in Table 1, and figure 3 shows the species distribution for the system. In all cases the $\mathrm{s}_{\mathrm{fit}}$ values $^{50}$ were minor than 0.010 for the titration of sulfathiazole alone, and minor than 0.015 for the titration of the Co(II)-sulfathiazole system. The analysis of random error ${ }^{52}$ gave a very satisfactory result for each constant. These good fits mean that the system is well represented by the proposed model.

Table 1. $\log$ values of protonations constants of sulfathiazole (HST) and its binding constants with cobalt(II) ion, at $25.0{ }^{\circ} \mathrm{C}, \mu=0.10 \mathrm{M}$ $(\mathrm{KCl})$

\begin{tabular}{lr}
\hline Equilibrium quotient & \multicolumn{1}{c}{$\log \beta$} \\
\hline$[\mathrm{HL}] /\left[\mathrm{L}^{-}\right]\left[\mathrm{H}^{+}\right]$ & $7.24(4)$ \\
{$\left[\mathrm{H}_{2} \mathrm{~L}^{+}\right] /[\mathrm{HL}]\left[\mathrm{H}^{+}\right]$} & $9.56(4)$ \\
{$[\mathrm{ML}] /\left[\mathrm{L}^{-}\right]\left[\mathrm{M}^{2+}\right]$} & $15.11(6)$ \\
{$[\mathrm{M}(\mathrm{OH}) \mathrm{L}] /\left[\mathrm{L}^{-}\right]\left[\mathrm{M}^{2+}\right]\left[\mathrm{OH}^{-}\right]$} & $7.67(6)$ \\
\hline
\end{tabular}

a Sulfathiazole, HST, is designed by HL. Co(II) is designed by M. The numbers in parentheses are the estimated errors in the last significant figure.

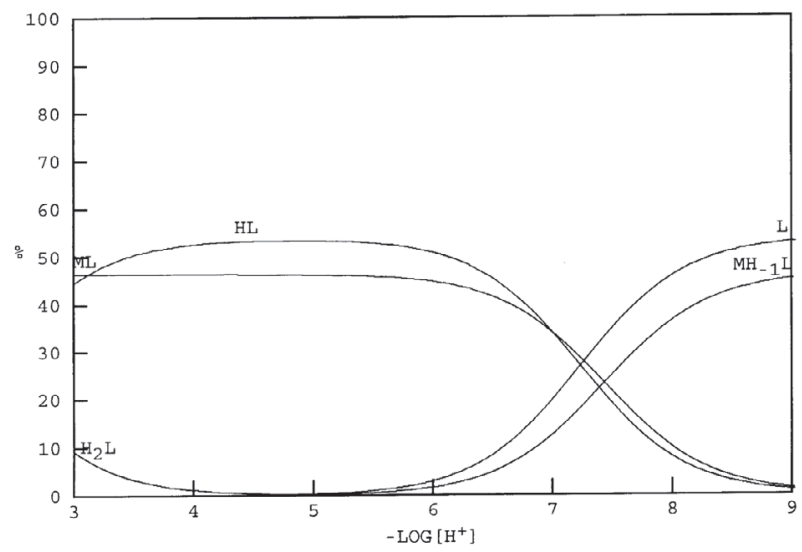

Figure 3. Species distribution curves of 1:2 Co(II)-sulfathiazole, at $25.0^{\circ} \mathrm{C}$ and $I=0.100 \mathrm{M}(\mathrm{KCl})$, as function of $-\log \left[\mathrm{H}^{+}\right]$for a solution initially containing $2.076 \times 10^{-3} \mathrm{M} \mathrm{HST}$ and $0.962 \times 10^{-3} \mathrm{M} \mathrm{Co}(\mathrm{II})$, where L represents the deprotonated ligand, ST , ML: [CoST $]^{+}$and $M_{-1} L:[C o(O H) S T] . \%=$ percent concentration with $\Sigma$ [ligand] $=100 \% . \mathrm{H}^{+}$and $\mathrm{OH}^{-}$are not shown.

\section{Electronic spectra}

Electronic spectra of metal complexes can provide valuable information related to bond and structure, since the colors are intimately related to the magnitude of the spacing between $d$ orbitals ${ }^{66}$. The wavelength of the absortion maxima, in $\mathrm{nm}$, are summarized in Table 2 for both aqueous solution \%the Co(II)sulfathiazole system and the $\mathrm{CoCl}_{2} \cdot 6 \mathrm{H}_{2} \mathrm{O}$ one $\%$ at different $\mathrm{p}[\mathrm{H}]$.

Table 2. $d$ - $d$ spectra in aqueous solution $\left(\lambda_{\max }\right)$ of the $\mathrm{Co}(\mathrm{II})$-sulfathiazole and $\mathrm{CoCl}_{2} \cdot 6 \mathrm{H}_{2} \mathrm{O}$ systems, at different $\mathrm{p}[\mathrm{H}] ; \mu=0,10 \mathrm{M}$ $(\mathrm{KCl}) ; \mathrm{T}=25^{\circ} \mathrm{C}$

\begin{tabular}{lccccc}
\hline $\mathrm{p}[\mathrm{H}]$ & $\mathrm{Co}(\mathrm{II})-\mathrm{HST}$ & system (aq) & \multicolumn{4}{c}{$\mathrm{CoCl}_{2} \cdot 6 \mathrm{H}_{2} \mathrm{O}(\mathrm{aq})$} \\
$c a$. & $\lambda, \mathrm{nm}$ & $(\mathrm{p}[\mathrm{H}])$ & $\lambda, \mathrm{nm}$ & $\left(\varepsilon, \mathrm{M}^{-1} \cdot \mathrm{cm}^{-1}\right)$ & $(\mathrm{p}[\mathrm{H}])$ \\
\hline 2 & 511 & $(2.023)$ & 510 & $(6)$ & $(2.054)$ \\
4 & 474 & $(4.029)$ & 510 & $(7)$ & $(4.105)$ \\
8 & 475 & $(8.103)$ & $508 \& 645$ & $(6) \&(4)$ & $(8.535)$ \\
\hline
\end{tabular}

The electronic spectrum produced by the aqueous solution of $\mathrm{CoCl}_{2} \cdot 6 \mathrm{H}_{2} \mathrm{O}$ correspond to that arising from the octahedral $\left[\mathrm{Co}\left(\mathrm{H}_{2} \mathrm{O}\right)_{6}\right]^{2+}$ complex ${ }^{67}$. These spectra have not showed dependence with $\mathrm{pH}$ at the measurement one ( $\mathrm{pH} \approx 2 ; 4$ and 8 ). Only at $\mathrm{pH} \approx 8$ it was possible to observe two of the three possible electronic transitions: $v_{2}\left[{ }^{4} \mathrm{~T}_{1 \mathrm{~g}} \rightarrow{ }^{4} \mathrm{~A}_{2 \mathrm{~g}}\right]$ $=645 \mathrm{~nm}$ and $\mathrm{v}_{3}\left[{ }^{4} \mathrm{~T}_{1 \mathrm{~g}} \rightarrow{ }^{4} \mathrm{~T}_{1 \mathrm{~g}}(\mathrm{P})\right]$ at $508 \mathrm{~nm}$, while the $\mathrm{v}_{1}\left[{ }^{4} \mathrm{~T}_{1 \mathrm{~g}} \rightarrow{ }^{4} \mathrm{~T}_{2 \mathrm{~g}}\right]$ transition is expected at $1200 \mathrm{~nm}$, outside the measured range ${ }^{67}$. On the contrary, the spectra of aqueous solutions of the system $\mathrm{Co}$ (II)sulfathiazole display $\mathrm{pH}$ dependence. At $\mathrm{pH} \approx 2$ the wavelength of the absorption maxima were the same for both solutions $\left(\mathrm{CoCl}_{2} \cdot 6 \mathrm{H}_{2} \mathrm{O}\right.$ and the system $\mathrm{Co}$ (II)-HST), suggesting that the predominating specie could be the $\left[\mathrm{Co}\left(\mathrm{H}_{2} \mathrm{O}\right)_{6}\right]^{2+}$ complex in both systems. However, at $\mathrm{pH}$ $c a .4$ and $c a$. 8 , the $\lambda_{\text {max. }}$ were shifted to lower wavelength in the Co(II)HST system with respect to the $\left[\mathrm{Co}\left(\mathrm{H}_{2} \mathrm{O}\right)_{6}\right]^{2+}$ complex, suggesting an increase in the ligand field strength ${ }^{66}$. In the region of $\mathrm{pH} \approx 2$, out of our range of potentiometric measurements, the predominant specie would be the $\left[\mathrm{Co}\left(\mathrm{H}_{2} \mathrm{O}\right)_{6}\right]^{2+}$ complex, so, it is not any complex between HST and $\mathrm{Co}(\mathrm{II})$ at this $\mathrm{pH}$. However, at $\mathrm{pH} \approx 4$ and $\mathrm{pH} \approx 8$, where, in agreement with potentiometric measurements, the ML and $\mathrm{M}(\mathrm{OH}) \mathrm{L}$ (where $\mathrm{L}$ represents $\mathrm{ST}^{-}$) are, respectively, the predominant species, the wavelength of the absorption maxima were shifted at very similar $\lambda$, suggesting that the coordination sphere might be similar in both cases and different from the $\left[\mathrm{Co}\left(\mathrm{H}_{2} \mathrm{O}\right)_{6}\right]^{2+}$ one. The spectra of aqueous solutions of the system $\mathrm{Co}$ (II)-citrate display too some $\mathrm{pH}$ dependence: in an equimolar $\mathrm{Co}$ (II)-citrate solution at $\mathrm{pH} \approx 6$, where complex [CoL] predominates (L represents citrate), $\lambda_{\text {max }}$ is observed at $516 \mathrm{~nm}$, while, at $\mathrm{pH} \approx 10$, where complex $[\mathrm{Co}(\mathrm{OH}) \mathrm{L}]^{2-}$ is the only specie present, $\lambda_{\text {max }}$ shifts to $534 \mathrm{~nm}$ and a new band occurs at $\lambda_{\max }=726 \mathrm{~nm}^{47}$. The diffuse reflectance spectrum of $\left[\mathrm{Co}^{\mathrm{II}}(\mathrm{ST})_{2}\left(\mathrm{H}_{2} \mathrm{O}\right)_{4}\right]$, which was measured in the $400-900 \mathrm{~nm}$ range ${ }^{65}$, suggests an octahedral geometry around the metal ion $^{66}$. There can be observed two of the three possible electronic transitions: $v_{2}\left[{ }^{4} \mathrm{~T}_{1 \mathrm{~g} \rightarrow}{ }^{4} \mathrm{~A}_{2 \mathrm{~g}}\right]=610 \mathrm{~nm}$ and $\mathrm{v}_{3}\left[{ }^{4} \mathrm{~T}_{1 \mathrm{~g} \rightarrow} \rightarrow \mathrm{T}_{1 \mathrm{~g}}(\mathrm{P})\right]$, multiple structured at 532, $480(\mathrm{sh})$ and $435(\mathrm{sh}) \mathrm{nm}$. The $\left.\mathrm{v}_{1}{ }_{1}{ }^{4} \mathrm{~T}_{1 \mathrm{~g}} \rightarrow{ }^{4} \mathrm{~T}_{2 \mathrm{~g}}\right]$ transition is expected at $1300 \mathrm{~nm}$, outside the measured range ${ }^{65}$. Six coordinate complexes of $\mathrm{Co}(\mathrm{II})$ (high spin), with only nitrogen donor atoms, exhibit a transition $v_{3}\left[{ }^{4} \mathrm{~T}_{1 \mathrm{~g} \rightarrow}{ }^{4} \mathrm{~T} / \mathrm{g}(\mathrm{P})\right]$ at ca. $475 \mathrm{~nm}$ : $\left[\mathrm{Co}(\mathrm{en})_{3}\right]^{2+}: 476$; $\left[\mathrm{Co}\left(\mathrm{NH}_{3}\right)_{6}\right]^{2+}: 474 \mathrm{~nm}^{68}$. The electronic spectra of aqueous solutions of the system Co(II)-HST let us suggest that the coordination between $\mathrm{Co}(\mathrm{II})$ and sulfathiazolate $\left(\mathrm{ST}^{-}\right)$in both species, $[\mathrm{CoST}]^{+}(\mathrm{aq})$ and $[\mathrm{CoST}(\mathrm{OH})](\mathrm{aq})$, might be involved nitrogen atoms.

\section{Structural data and topological analysis}

Optimized geometries of Sulfathiazole, HST, and Sulfathiazolate, 
$\mathrm{ST}^{-}$, along with the atomic labels used and selected geometrical parameters have been displayed in Figure 4. Although it seems to be reasonable to assume from previously reported results of experimental studies ${ }^{69-71}$ that HST, in solid state, possesses the $\mathrm{H}$ binding at the tiazolic $\mathrm{N}$, in order to predict quantumchemically the different stabilities of both possible structural isomers, the total energies and vibrational frequencies of molecules with different $\mathrm{H}$ connectivity were computed. At B3LYP/6-31+G** level of theory the isomer with the $\mathrm{H}$ atom bonded at amido $\mathrm{N}$ atom was shown to be just slightly favored over the $\mathrm{N}-\mathrm{H}$ tiazolic structure by $1.2 \mathrm{kcal} \mathrm{mol}^{-1}\left(5.1 \mathrm{~kJ} \mathrm{~mol}^{-1}\right)$.

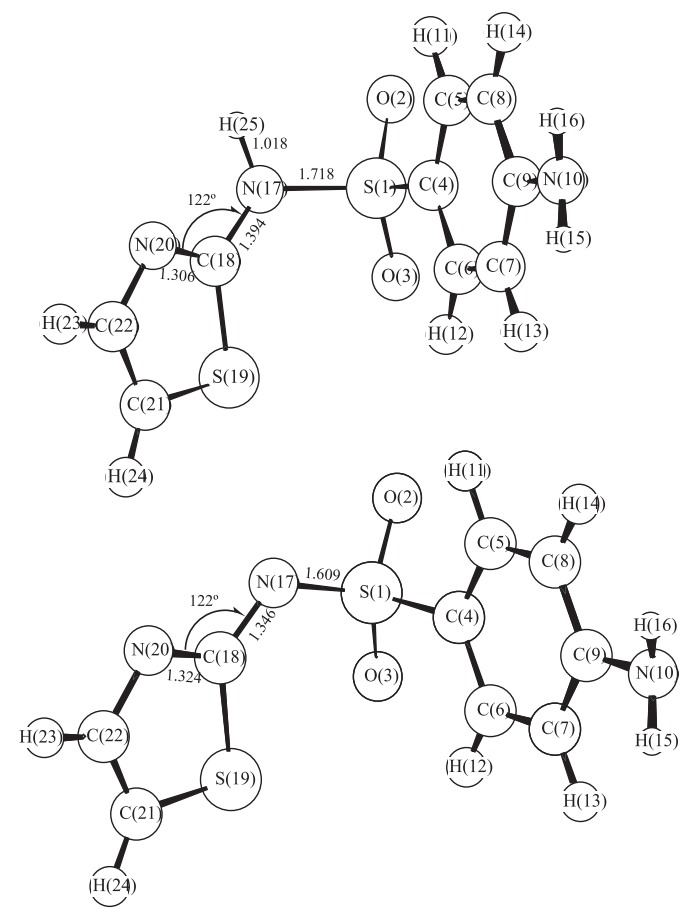

Figure 4. B3LYP/6-31+G** calculated structures of Sulfathiazole, HST, and Sulfathiazolate, $S T^{-}$

Both species possess a structure where the six and five member rings tend to be out of the plane. The angles between both rings are $95^{\circ}$ in HST and $100^{\circ}$ in ST$^{-}$.

Topological properties of the electronic charge density calculated at different BCP's for both studied species reveals that the bonds in HST and $\mathrm{ST}^{-}$are typical shared or covalent interactions, that is to say high $\rho_{b}$ values, relatively high negative $\nabla^{2} \rho_{b}$ values and a relationship $\left|\lambda_{1}\right| / \lambda_{3}>1$. For example, in a C-C bond the $\rho_{b}$ values are 0.3214 and $0.3231 \mathrm{au}$, the $\nabla^{2} \rho_{\mathrm{b}}$ values are -0.8817 and $0.8940 \mathrm{au},\left|\lambda_{1}\right| / \lambda_{3}$ are 2.2013 and 2.2233 and $E_{\mathrm{b}}$ values are -0.3437 au and -0.3469 au for HST and ST-, respectively. In a C-N bond the $\rho_{\mathrm{b}}$ values are $0.3189 \mathrm{au}$ and $0.3117 \mathrm{au}$, the $\nabla^{2} \rho_{\mathrm{b}}$ values are -0.9406 au and $-0.8934 \mathrm{au},\left|\lambda_{1}\right| / \lambda_{3}$ is 2.0165 and 1.9364 and $E_{\mathrm{b}}$ values are 0.4164 au and -0.4122 au for HST and ST $^{-}$, respectively.

For S-O bonds the $r_{b}$ values are rather lower (i.e. 0.2867 au in HST) than those corresponding to C-C and C-N bonds and $\nabla^{2} \rho_{\mathrm{b}}>0$ (i.e. $0.7390 \mathrm{au}$ in HST). However, because $E_{\mathrm{b}}<0$ (i.e. $-0.3470 \mathrm{au}$ ), these bonds can be well described as covalent polarized. Figure 5 shows the Laplacian of the electronic charge density for the HST and $\mathrm{ST}^{-}$structures. It can be seen that the BCP's corresponding to the bonds are found in a region of charge concentration, a fact that allows us to confirm that those bonds are mainly covalent in character. On the other hand, it is clear in the figure that the bond $\mathrm{CP}$ corresponding to the $\mathrm{S}-\mathrm{O}$ interactions are located near regions characterized by an electronic charge density depletion. These findings suggest that the S-O bonds can be well described as an interaction with polar character.

Slight changes can be observed when the contour map of ST- is compared with the contour map corresponding to the protonated one, Figure 5a and b, respectively. However, the changes observed after the deprotonation could influence in the coordination ability of the ligand.

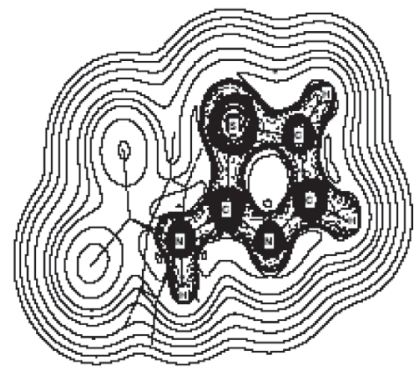

(a)

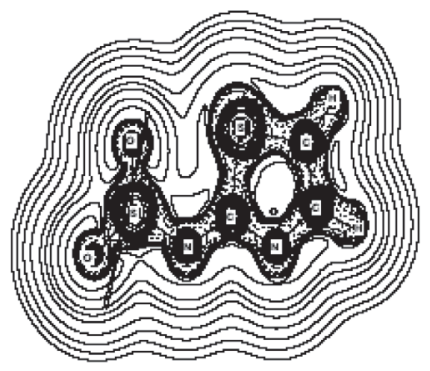

(b)
Figure 5. Laplacian of the electronic charge density of HST (a) and ST (b) in a plane containing the thiazolic ring. Broken lines represent regions of electronic charge concentration, and solid lines denote regions of electronic charge depletion. BCP are indicated with black circles. The molecular graph is also indicated. The contours of the Laplacian of the electronic charge density increase and decrease from a zero contour in steps of $\pm 2 \times 10^{n}, \pm 4 \times 10^{n}$, and $\pm 8 \times 10^{n}$, with $n$ beginning at -3 and increasing by unity

In order to gain more insight about the possible sites of coordination between the ligand and the metal ion in the species $\mathrm{ML}^{+}$and $\mathrm{ML}(\mathrm{OH})$, we undertook a topological analysis of the Laplacian of the electronic density. Therefore, NBCP have been determined on the nitrogen and oxygen atoms in both structures. Results are collected in Table 3. A single NBCP is found at amine nitrogen (N10) pointing to the apex of the pyramid in both cases. This is what can be expected from low degree of conjugation for these amine groups with an aromatic ring. In the same way, in both structures a single NBCP is encountered in N20. This NBCP is coplanar with the ring in agreement with a $s p^{2}$ hybridization.

On the other hand, in HST two NBCP are found for the N17. The first of these NBCP is located at the apex of the pyramidic nitrogen (the place where the lone electron pair is usually represented). The second NBCP appears pointing towards the base of the pyramid. The value of $\nabla^{2} \rho$ for the first NBCP is larger than in the second one. The existence of these two NBCP can be explained at the light of the conjugation between the $\mathrm{NH}$ group and the thiazolic ring. In absence of conjugation we can expect a single local maximum of charge concentration, a NBCP, corresponding to the lone electron pair placed in a hybrid orbital pointing to the apex of the pyramid. However, because the NH is conjugated, the electron pair is more similar to a two lobed $p$ orbitals than to a hybrid orbital with a single lobe. Since there is not a pure $p$ orbital, the two lobes are not equivalent. Contrarily, in $\mathrm{ST}^{-}$a single NBCP is encountered in N17. This NBCP is coplanar with the N-C-N bond, in agreement with $s p^{2}$ hybridization.

On the $\mathrm{O}$ atoms of the $\mathrm{SO}_{2}$ group, two NBCP are found, compatible with two lone electron pairs corresponding to an oxygen atom with $s p^{2}$ hybridization. It can be seen in Table 3 that the $\nabla^{2} \rho$ values on $\mathrm{O}$ atoms are significantly higher than on $\mathrm{N}$ atoms. Anyway, we discard this site of binding of the ligand because, although Co(II) is able to form complexes in which the metal ion is coordinated by means of $\mathrm{O}$ atoms, $\mathrm{N}$ atoms or both, in all cases these $\mathrm{O}$ atoms are binding to $\mathrm{C}$ atoms, not to $\mathrm{S}$ ones ${ }^{68}$. Besides, in two solid cobalt compounds obtained previously between sulfathiazole and $\mathrm{Co}$ (II) 
$\left(\left[\mathrm{Co}(\mathrm{ST})_{2}\left(\mathrm{H}_{2} \mathrm{O}\right)_{4}\right]\right.$ and $\left.\left[\mathrm{Co}(\mathrm{ST})_{2}\left(\mathrm{H}_{2} \mathrm{O}\right)_{3}\right]_{\mathrm{n}}\right)$, the IR bands attributed to the $\mathrm{SO}_{2}$ vibrations remain unaltered, suggesting no interaction of the $-\mathrm{SO}_{2}$-group with the metal ion ${ }^{65}$.

When the values of $\nabla^{2} \rho$ are compared at the different nonbonded critical points on $\mathrm{N}$ atoms of the two species, the $\mathrm{NBCP}$ at the thiazolic nitrogen (N20) exhibits the highest concentration of charge (see Table 3 ). This finding suggests that the coordination $\mathrm{Co}(\mathrm{II})-\mathrm{ST}$ of both species, $\mathrm{ML}^{+}$and $\mathrm{M}(\mathrm{OH}) \mathrm{L}$, might be through a nitrogen atom and probably from the thiazolic ring (N20).

Table 3. Values of Laplacian of the charge density, $\nabla^{2} \rho$ [au], at the Non-Bonded Critical Points (NBCP) of the nitrogen atoms in structures HST y $\mathrm{ST}^{-}$

\begin{tabular}{lcccc}
\hline Atom & HST & NBCP Position & ST $^{-}$ & NBCP Position \\
\hline N10 & -2.1513 & Pyramidal & -2.3858 & Pyramidal \\
N17 & -1.3552 & Top and down & -2.0866 & In plane \\
& -2.3731 & of plane & & \\
N20 & -2.5694 & In plane & -2.4654 & In plane \\
O2 & -4.0292 & In plane & -4.0113 & In plane \\
& -4.0967 & & -4.0364 & \\
O3 & -4.0501 & In plane & -3.9485 & In plane \\
& -4.1044 & & -3.9739 & \\
\hline
\end{tabular}

\section{Structure of the complexes}

It is not possible only from potentiometric data to know which are the coordination points; nevertheless, in order to infer which might be possible coordination atom, we analyzed electronic spectra and the energy of MO of HST and ST'. Although MO calculations were carried out on gas-phase models, the obtained results are comparable with the experimental ones. In this sense, predictions of pKa's of organic acids ${ }^{72,73}$ and of structural data of cyano- and dicyanopolyacetylene cations ${ }^{74}$, are some examples.

In spite of their poor capacity of coordination in acidic me$\mathrm{dia}^{75}$, and surprisingly for us, we found the specie $[\mathrm{Co}(\mathrm{ST})]^{+}(\mathrm{aq})$ at $\mathrm{pH} 3-5^{76}$. Although the synthesis of metal complexes of sulfathiazole at the solid state has been reported, the structural determination is often incomplete and conflicting ${ }^{77,78}$. Relating to sulfathiazole metal complexes, different compounds were reported, in which the sulfathiazole moiety acts with a high versatility in its coordination ability. For example, with $\mathrm{Zn}(\mathrm{II})$, the drug acts as a bridging ligand through both the $\mathrm{N}_{\text {amino }}$ and $\mathrm{N}_{\text {thiazole }}$ atoms ${ }^{78}$. As a neutral ligand, the HST acts as monodentate, binding the metal ion through the $\mathrm{N}_{\text {amino }}$ atom ${ }^{79}$. As a deprotonated ligand, $\mathrm{ST}^{-}$has a variety of coordination behavior, e.g., besides the $\mathrm{Zn}(\mathrm{II})-\mathrm{ST}$ complex ${ }^{78}$, in $\mathrm{Cu}(\mathrm{II})$ complexes, coordination through the N-thiazole atom could be seen, and, in another case, the sulfathiazolato exhibits bidentate behavior linking the metal ion through the $\mathrm{N}_{\text {thiazolic }}$ and the $\mathrm{N}_{\text {sulfonamido }}$ atoms ${ }^{80}$. More recently, we have analyzed the interaction of mercury(II) with sulfathiazole: IR and NMR spectral studies suggested a coordination of $\mathrm{Hg}(\mathrm{II})$ with the $\mathrm{N}_{\text {thiazolic }}$ atom, unlike related $\mathrm{Hg}$-sulfadrugs compounds $^{81}$.

As we said before, there are many Co(II) complexes in which the donor atoms are $\mathrm{N}$ ones, and many others in which the bond $\mathrm{Co}$ (II)-ligand is by means of $\mathrm{O}$ atoms ${ }^{67,68,82}$. The cobalt in vitamin $\mathrm{B}_{12}$ is coordinated to five $\mathrm{N}$ atoms, four attributed to a tetrapyrrole (corrin); the sixth ligand is $\mathrm{C}$, provided either by $\mathrm{C} 5$ of deoxyadenosine in enzymes such as methylmalonyl-CoA (fatty acid metabolism) or by a methyl group in the enzyme that synthesizes the amino acid methionine in bacteria ${ }^{83}$. Recently, we determined the crystal structure of $\left[\mathrm{Co}^{\mathrm{II}}(\mathrm{ST})_{2}\left(\mathrm{H}_{2} \mathrm{O}\right)_{3}\right]_{\mathrm{n}}(\mathrm{ST}=$ sulfathiazolate $)$, - which molecular formula differ from $\left[\mathrm{Co}^{\mathrm{II}}(\mathrm{ST})_{2}\left(\mathrm{H}_{2} \mathrm{O}\right)_{4}\right]$ in only one water molecule-, where the cobalt atom exhibits a distorted octahedral coordination sphere, and three of the donor atoms are nitrogen: two $\mathrm{N}_{\text {thiazolic }}$ and one $\mathrm{N}_{\text {amine }}$. Other donor atoms are oxygen from water molecules ${ }^{65}$. In the Co(II)-citric acid system ${ }^{47}$ it could be found the predominance of the mononuclear species [CoL] $]^{-}(\mathrm{L}$

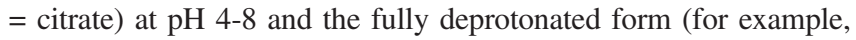
$\left.[\mathrm{CoL}(\mathrm{OH})]^{4-}\right)$ at $\mathrm{pH} 8-10$, with minor $\%$ of $\left[\mathrm{CoL}_{2}\right]^{4-}$ at $\mathrm{pH} 5-8$ and $[\mathrm{CoLH}]$ and $\mathrm{Co}(\mathrm{II})(\mathrm{aq})$ at $\mathrm{pH}<4.5$. Complex of $\mathrm{Co}$ (II) with $4-$ methylimidazole-5-carbaldehyde showed that the ligand can act as a bidentate one, with $\mathrm{N}$ and $\mathrm{O}$ as donor atoms: the pyridine-like nitrogen atom of the imidazole ring and the oxygen atom of $\mathrm{CHO}$ group, participate in the formation of the coordination bonds, with the formation of a weak five membered quelate ring. The structure of the complex at the solid state, with 2 ligand per Co(II), is conserved in solution ${ }^{84}$.

In the Co(II)-sulfathiazole system, in aqueous solution, it could be observed species coordinates with only one molecule of ligand, different from these last systems. When another molecule of sulfathiazole come into the coordination sphere, the resultant complex precipitates.

The electronic spectrum observed in the aqueous solution of the system Co(II)-HST, at the $\mathrm{pH}$ of predominance of both species $\mathrm{Co}(\mathrm{II})-\mathrm{ST}$, might be suggested that there could be a nitrogen atom involved in the coordination between $\mathrm{Co}$ (II) and ST- in both complexes.

It is possible to suggest that the coordination of $\mathrm{Co}(\mathrm{II})$ with sulfathiazole in both species, $\mathrm{ML}$ and $\mathrm{M}(\mathrm{OH}) \mathrm{L}$, in aqueous solution, might be through a $\mathrm{N}$ atom (in agreement with electronic spectra), and this $\mathrm{N}$ atom might be probably from the thiazolic ring one (in agreement with theoretical calculations).

\section{CONCLUSIONS}

Two complex species were detected by potentiometric measurements in the aqueous $\mathrm{Co}(\mathrm{II})$-sulfathiazole system. Spectroscopic studies of the system and MO calculations of HST and $\mathrm{ST}^{-}$suggest that, in the coordination between $\mathrm{Co}(\mathrm{II})$ and sulfathiazole in aqueous solutions a $\mathrm{N}$ atom of the ligand might be involved, probably the thiazolic one.

\section{ACKNOWLEDGMENTS}

We thank the National University at Rosario and its Research Council (CIUNR) and SECYT UNNE for financial support.

\section{REFERENCES}

1. Smith, A.; Martell, A. E.; Critical Stability Constants, Plenum Press: New York, 1989, vol. 6, suppl. 2.

2. Thaler, A.; Heidari, N.; Cox, B.; Schneider, H.; Inorg. Chim. Acta 1999, $286,160$.

3. Navon, N.; Burg, A.; Cohen, H.; van Eldik, R.; Meyerstein, D.; Inorg. Chem. 2002, 41, 2927.

4. Comuzzi, C.; Melchior, A.; Polese, P.; Portanova, R.; Tolazzi, M.; Inorg. Chim. Acta 2003, 355, 57.

5. Bencini, A.; Bianchi, A.; Fornasari, P.; Giorgi, C.; Paoletti, P.; Valtancoli, B.; Polyhedron 2002, 21, 1329.

6. Jones, R. D.; Summerville, D. A.; Basolo, F.; Chem. Rev. 1979, 79, 139

7. Cabani, S.; Ceccanti, N.; Tinè, M. R.; Pure Appl. Chem. 1991, 63, 1455.

8. Tolman, W. B.; Acc. Chem. Res. 1997, 30, 227.

9. Zang, W. ; van Eldik, R.; J. Chem. Soc., Dalton Trans. 1993, 111.

10. Schindler, S. ; Hubbard, C. D.; van Eldik, R.; Chem. Soc. Rev. 1998, $27,387$.

11. Franz, K. J.; Lippard, S. J.; J. Am. Chem. Soc. 1999, 121, 10504.

12. Bencini, A.; Bianchi, A.; Giorgi, C.; Paoletti, P.; Valtancoli, B.; Ceccanti, N.; Pardini, R.; Polyhedron 2000, 19, 2441 and references cited therein. 
13. Niederhoffer, E. C.; Timmons, J. H.; Martell, A.; Chem. Rev. 1984, 84, 137.

14. Martell, A.; Sawyer, D. T.; Oxygen Complexes and Oxygen Activation by Transition Metals, Plenum Press: New York, 1988.

15. Comuzzi, C.; Grespan, M.; Polese, P.; Portanova, R.; Tolazzi, M.; Inorg. Chim. Acta 2001, 321, 49.

16. Corden, B. B.; Drago, R. S.; Perito, R. P.; J. Am. Chem. Soc. 1985, 107, 2903.

17. Comuzzi, C.; Melchior, A.; Polese, P.; Portanove, R.; Tolazzi, M.; Inorg. Chem. 2003, 42, 8214 .

18. Melchior, A.; Peressini, S.; Portanova, R.; Sangregorio, C.; Tavagnacco, C.; Tolazzi, M.; Inorg. Chim. Acta 2004, 357, 3473.

19. Carvalho, E.; Aasa, R.; Göthe, P.; J. Inorg. Biochem. 1996, 62, 147.

20. Bonander, N.; Vänngard, T.; Tsai, L.; Langer, V.; Nar, H.; Sjölin, L.; Proteins 1997, 27, 385.

21. Adrait, A.; Jacquamet, L.; Pape, L.; González de Peredo, A.; Aberdam, D.; Hazemann, J. L.; Latour, J. M.; Michaud-Soret, I.; Biochemistry 1999, 38, 6248.

22. Strand, K. R.; Karlsen, S.; Andersson, K. K.; J. Biol. Chem. 2002, 277, 34229.

23. Sadler, P. J.; Adv. Inorg. Chem. 1991, 36, 1 .

24. Ferrer, E.; González-Baró, A.; Castellano, E.; Piro, O.; Williams, P.; J. Inorg. Biochem. 2004, 98, 413 .

25. Mandell, G.; Sande, M. In Las Bases Farmacológicas de la Terapéutica; Goodman, A.; Gilman, L., eds.; $6^{\text {th }}$ ed., Ed. Médica Panamericana: Buenos Aires, 1981.

26. Alzuet, G.; Ferrer-Llusar, S.; Borrás, J.; Server-Carrió, J.; Martínez-Máñez, R. J.; Inorg. Biochem. 1999, 75, 189.

27. Bult, A. In Metal Ions in Byological Systems; Sigel, H., ed.; Ed. Marcel Decker: New York, 1983, cap. 16, p. 261.

28. Nogrady, Th.; Medicinal Chemistry, $2^{\text {nd }}$ ed., Oxford University Press: New York, 1988, p. 383.

29. Barnhart, E. R., ed.; Physician's Desk Reference, PDR, $43^{\text {rd }}$ ed., Medical Economics: New York, 1989.

30. García-Raso, A.; Fiol, J. J.; Rigo, S.; López-López, A.; Molins, E.; Espinosa, E.; Borrás, E.; Alzuet, G.; Borrás, J.; Castiñeiras, A.; Polyhedron 2000, 19, 991 .

31. Casanova, J.; Alzuet, G.; Borrás, J.; David, L.; Gatteschi, D.; Inorg. Chim. Acta 1993, 211, 183.

32. Bonamartini-Corradi, A.; Gozzoli, E.; Menabue, L.; Saladini, M.; Battaglia, L. P.; Sgarabotto, P. J.; Chem. Soc. Dalton Trans. 1994, 273.

33. Ferrer, S.; Borrás, J.; Garcia-España, E.; J. Inorg. Biochem. 1990, 39, 297.

34. Supuran, C. T.; Mincione, F.; Scozzafava, A.; Briganti, F.; Mincinone, G.; Ilies, M. A.; Eur. J. Med. Chem. 1998, 33, 247.

35. Supuran, C. T.; Scozzafava, A.; J. Enzyme Inhib. Med. Chem. 1997, 13, 37.

36. Jitianu, A.; Ilies, M. A.; Scozzafava, A.; Supuran, C. T.; Main Group Met. Chem. 1997, 20, 14.

37. Scozzafava, A.; Menabuoni, L.; Mincione, F.; Briganti, F.; Mincinone, G.; Supuran, C. T.; J. Med. Chem. 1999, 42, 2641.

38. Agrawal, V. K.; Singh, J.; Khadikar, P. V.; Supuran, C. T.; Bioorg. Med. Chem. Lett. 2006, 16, 2044.

39. Barboiu, M.; Cimpoesu, M.; Guran, C.; Supuran, C. T.; Metal Base Drugs 1996, 3, 227.

40. Briganti, F.; Scozzafava, A.; Supuran, C. T.; Eur. J. Med. Chem. 1997, 32, 901.

41. Blasco, F.; Perelló, L.; Latorre, J.; Borrás, J.; Garciá-Granda, S. J.; Inorg. Biochem. 1996, 61, 143.

42. Lippard, S. J.; Berg, J. M.; Principles of Bioinorganic Chemistry, University Science Books: Mill Valley, CA, 1994.

43. Fraústo da Silva, J. J. R.; Williams, R. J. P.; The Biological Chemistry of the Elements, Clarendon Press: Oxford, 1997.

44. Hamilton, E. M. N.; Grospper, S. A. S.; The Biochemistry of Human Nutrition, West Publ. Co: New York, 1987, p. 298-301.

45. Helis, H. M.; de Meester, P.; Hogdson, D. J.; J. Am. Chem. Soc. 1976, 99, 3309 .

46. Waldbott, G. L.; Health Effects of Environmental Pollutants, C. V. Mosby Co.: St. Louis, MO, 1973.

47. Kotsakis, N.; Raptopoulou, C. P.; Terzis, A.; Giapintzakis, J.; Jakusch, T.; Kiss, T.; Salifoglou, A.; Inorg. Chem. 2003, 42, 22.

48. Schwarzenbach, G.; Flaschka, H.; Complexometric Titration, Methuen: London, 1969, p. 242-244.

49. Kolthoff, I. M.; Sandell, E. B.; Meehan, E. J.; Bruckenstein, S.; Análisis Químico Cuantitativo, $6^{\circ}$ ed., Editorial Nigar S.R.L.: Buenos Aires, 1979, p. $809-811$.
50. Martell, A. E.; Motekaitis, R. J.; Determination and Use of Stability Constants, VCH, Publishers, Inc.: New York, $2^{\text {nd }}$ ed., 1992.

51. Bordignon-Luiz, M. T.; Szpoganicz, B.; Rizzotto, M.; Martell, A. E.; Basallote, M.; Inorg. Chim. Acta 1997, 254, 345

52. Olivieri, A.; Escandar, G.; Anal. Lett. 1997, 30, 1967.

53. Aires, V.; Zaccaron, C.; Neves, A.; Szpoganicz, B.; Inorg. Chim. Acta 2003 , 353,82 .

54. Farmacopea Nacional Argentina, $6^{\circ}$ ed., Editorial Codex S. A.: Buenos Aires, 1978.

55. Burriel, F.; Lucena, F.; Arribas, S.; Hernández, J.; Química analítica cualitativa, Paraninfo: Madrid, 1992.

56. Baes, C.; Mesmer, R.; The hydrolysis of cations, John Wiley \& Sons: USA, 1976, p. 238

57. Bader, R. F. W.; Atoms in Molecules. A Quantum Theory, University Press: Oxford, 1990

58. Bader, R. F. W.; J. Phys. Chem. A 1998, 102, 7314

59. Bader, R. F. W.; Chem. Rev. 1990, 91, 893

60. HyperChem Release 5.0 for Windows 1996, Hypercube Inc., USA.

61. Frisch, M. J.; Trucks, G. W.; Schlegel, H. B.; Scuseria, G. E.; Robb, M A.; Cheeseman, J. R.; Zakrzewski, V. G.; Montgomery, J. A.Jr.; Stratmann, R. E.; Burant, J. C.; Dapprich, S.; Millam, J. M.; Daniels, A. D.; Kudin, K. N.; Strain, M. C.; Farkas, O.; Tomasi, J.; Barone, V.; Cossi, M.; Cammi, R.; Mennucci, B.; Pomelli, C.; Adamo, C.; Clifford, S.; Ochterski, J.; Petersson, G. A.; Ayala, P. Y.; Cui, Q.; Morokuma, K.; Malick, D. K.; Rabuck, A. D.; Raghavachari, K.; Foresman, J. B.; Cioslowski, J.; Ortiz, J. V.; Baboul, A. G.; Stefanov, B. B.; Liu, G.; Liashenko, A.; Piskorz, P.; Komaromi, I.; Gomperts, R.; Martin, R. L.; Fox, D. J.; Keith, T.; Al-Laham, M. A.; Peng, C. Y.; Nanayakkara, A.; Gonzalez, C.; Challacombe, M.; Gill, P. M. W.; Johnson, B.; Chen, W.; Wong, M. W.; Andres, J. L.; Gonzalez, C.; Head-Gordon, M.; Replogle, E. S.; Pople, J. A.; Gaussian 98, Revision A.7, Gaussian, Inc., Pittsburgh PA, 1998.

62. Becke, A. D.; J. Chem. Phys. 1993, 98, 5648.

63. Lee, C. ; Yang, W.; Parr, R.G.; Phys. Rev. B: Condens. Matter Mater. Phys. 1988, 37, 785

64. Biegler-König, F. W.; Bader, R. F. W.; Tang, T. H.; J. Comput. Chem. 1982, 13,317

65. Bellú, S.; Hure, E.; Trapé, M.; Trossero, C.; Molina, G.; Drogo, C. Williams, P. A. M.; Atria, A. M.; Muñoz Acevedo, J.C.; Zacchino, S.; Sortino, M.; Campagnoli, D.; Rizzotto, M.; Polyhedron 2005, 24, 501.

66. Huheey, J.; Keiter, E.; Keiter, R.; Inorganic Chemistry: Principles of Structure and Reactivity, Harper Collins: New York, 1993.

67. Cotton, F. A.; Wilkinson, G.; Advanced Inorganic Chemistry, $4^{\text {th }}$ ed., Wiley: New York, 1980.

68. Lever, A. B. P.; Inorganic Electronic Spectroscopy, $2^{\text {nd }}$ ed., Elsevier: The Netherlands, 1984.

69. Kruger, G. J.; Gafner, G.; Acta Crystallogr. 1971, 27, 326.

70. Kruger, G. J. Gafner, G.; Acta Crystallogr. 1972, 28, 272.

71. Chan, F. C.; Anwar, J.; Cernik, R.; Barnes, P.; Wilson, R. M.; J. Appl. Crystallogr. 1999, 32, 436.

72. Liptak, M. D.; Shields, G. C.; J. Am. Chem. Soc. 2001, 123, 7314.

73. Fu, Y.; Liu, L.; Li, R.-Q.; Liu, R.; Guo, Q.-X. J.; J. Am. Chem. Soc. 2004, $126,814$.

74. Sungyul, L. J.; J. Phys. Chem. 1996, 100, 13959.

75. Alzuet, G.; Ferrer-Llusar, S.; Borrás, J.; Server-Carrió, J.; Martínez-Máñez, R.; J. Inorg. Biochem. 1999, 75, 189.

76. Bellú, S.; Rizzotto, M.; Biocell 2004, 28, 221.

77. Torre, M. H.; Facchin, G.; Kremer, E.; Castellano, E.; Piro, O. E.; Baran, E. J.; J. Inorg. Biochem. 2003, 94, 200.

78. Casanova, J.; Alzuet, G.; Ferrer, S.; Borrás, J.; García-Granda, S.; PerezCarreño, E.; J. Inorg. Biochem. 1993, 51, 689.

79. Casanova, J.; Alzuet, G.; Borrás, J.; Timoneda, J.; García-Granda, S. Cándano-García, I.; J. Inorg. Biochem. 1994, 56, 65.

80. Casanova, J.; Alzuet, G.: Latorre, J.; Borrás, J.; Inorg. Chem. 1997, 36, 2052.

81. Bellú, S.; Hure, E.; Trapé, M.; Rizzotto, M.; Sutich, E.; Sigrist, M.; Moreno, V.; Quim. Nova 2003, 26, 188.

82. Barszcz, B.; Coord. Chem. Rev. 2005, 249, 2259

83. Bertini, I.; Gray, H.; Lippard, S.; Valentine, J.; Bioinorganic Chemistry, University Science Books: Mill Valley, CA, 1994.

84. Barszcz, B.; Hodorowicz, S. A.; Stadnicka, K.; Jablonska-Wawrzycka, A.; Polyhedron 2005, 24, 627 . 